\title{
Technology or Theology? \\ Music Beyond Technology
}

Martin Flašar / flasar@phil.muni.cz

Department of Musicology, Faculty of Arts, Masaryk University, Brno, CZ

\begin{abstract}
In different times of $20^{\text {th }}$ century technology played various roles in fulfilling listeners' and authors' expectations. The whole process reached its peak certainly in the post-war music development when technology was perceived either as a threat or a way to salvation of the contemporary music. The most remarkable problem represented a buying on future's credit. Leaders of European and American avant-garde swore on the future as the only guarantee of the contemporary music authenticity unmasking the obsolescence of yesterday's music. Not all composers were excited by technological possibilities of electronic media and left the optimistic mainstream sooner than others. Can music exist without technology? Can technology be possibly abandoned by composers and artists? And under what conditions?
\end{abstract}

\section{Keywords}

$20^{\text {th }}$ century music, technology, electronic media, avant-garde, Martin Heidegger, lannis Xenakis, György Ligeti, Pierre Boulez, Petr Nikl 
The issue addressed by this paper is, of course, paradoxical. There is nothing like music omitting use of technology. Although it might seem unlikely, music not only uses technological instruments but employs also rational procedures to being produced, organized, distributed and perceived. Technology is more than a mere artefact of the Western culture. It is a model of thinking and creating relationships as Carlos Gustavo Guerra reminds us. ${ }^{1}$

Other scholars, as Collins and Young, are going even further assuming that "music is a technology - the production and dissemination of music is a technological system, a system whose affordances have the ability to shape not only the musical content but also the extent to which music can be produced and distributed. On that basis, changes in technology are an integral part of the story of music. “2

\section{Technology as a problem of the $2^{\text {th }}$ century music}

Despite this claim, existing definitions of the technology related to music are very rare or weakly constructed.

Oxford Music Online Dictionaries do not supply autonomous subject entries "technology" or "technique", excluding a part of another more focused entries. In the Czech musical lexicography we do succeed in Dictionary of the Czech Musical Culture [Slovník české hudební kultury]. The entry „technika“ (which denotes technique / technic / technology) accents here following meanings: a set of procedures and tools (especially instruments) that serve the needs related to music. Since the 19th century, the terms technique / technic / technology has been used in relation to music in following senses:

1. The technique of playing, singing, or generally of musical interpretation.

2. Compositional techniques.

3. Technology of constructing musical instruments.

4. Re-production technology.

5. Technology as a subject, inspiration and structuring factor of musical works.

The $20^{\text {th }}$ century music had to solve one of the big riddles of the time - how to deal with newly emerging technologies?

In 1953 Martin Heidegger in his lecture The Question Concerning Technology [Die Frage nach der Technik] recommended the mankind to deal with technology in a spiritual way using means of arts to humanize it. Heidegger reaction was of those comforting ones, written face to face atomic technology threatening the very existence of the life on Earth. He accented the teleological function of technology, which supposed technology to remain an instrument controlled by man, not an aim of human efforts or even an object of worship.

1 GUERRA, Carlos Gustavo. The Mechanization of intelligence and the human aspects of music. In Eduardo Reck Miranda (ed.). Readings in Music and Artificial Intelligence. Harwood academic publishers, 2000. p. 207.

2 COLlins, Steve - YOUNG, Sherman. Beyond 2.0: The Future of Music. Equinox Publishing, 2014 , p. 9. 
Until $19^{\text {th }}$ century there have been technology supporting predominantly music production. All musical instruments were constructed as a sophisticated technological tools for making music. At latest since $19^{\text {th }}$ century technologies gradually replaced also further parts of the communication chain. Performers could have been replaced by music players, concert halls and opera theatres were replaced by a living-rooms immersed into tones of gramophone record or later of radio broadcasting. Collective experience of a social gathering was replaced by isolated intimacy of individualized listening.

Technology gradually subjected all aspects of musical experience. Surprisingly, ca until 1950's audience seemed relatively undisturbed by these immense technological changes. Only the new technological tools such as magnetic tape, oscillators, noise generators, filters, loudspeakers or microphones used for music processing and production opened the eyes (or better ears) of the audience.

\section{Theology - faith in the music of future}

For considerable part of audience as well as artists contemporary music has been substituted by music of future. Let's have following examples: Feruccio Busoni's Sketch of a New Aesthetic of Music (1907), Luigi Russolo's Art of Noise (1913), Edgard Varèse: The Liberation of Sound (1936) or John Cage and his Future of Music: Credo (1937). All of them legitimized contemporary music by music of future based on faith rather than on evidence in reality.

Compared with music of future, the yesterday's music definitely revealed its obvious obsolescence. In other words, post-war years represented a paradigm shift from outdated late romantic style (including Schoenberg school) to new-technology-based music. As an example of two clashing worlds we can choose Richard Strauss' Metamorphosen (1945) and Schaeffer's and Henry's Symphonie pour un homme seul (1950).

As Timothy Taylor asserts in his inspiring book Strange Sounds (2001), ${ }^{3}$ the French post-war techno-optimism rooted in 1830's. Already in thoughts of Saint-Simon or Charles Fourier can be found utopian ideas of dialogue between artists, scientists and technicians. ${ }^{4}$

Followingly, Taylor remind us Hobsbawm's verdict, that „as might have been expected, in era of extraordinary techno-scientific revolution, [the exogenous forces acting on the arts] were predominantly technological." ${ }_{5}$ And Leo Marx speaking on technocratic spirit or technocratic utopianism of the beginning of the $20^{\text {th }}$ century.

As an inspiring exclamation appeared Boulez's critique of Pierre Schaeffer and musique concréte. ${ }^{6}$ Except frequently criticized origin of material of the musique concréte and

3 TAYLOR, Timothy D. Strange Sounds: Music, Technology and Culture. NY, London: Routledge, 2001.

4 Compare BORN, Georgina. Rationalizing Culture: IRCAM, Boulez, .... Berkeley and Los Angeles: University of California Press, 1995, p. 71.

5 HOBSBAWM, Eric. The Age of extremes. Vintage, 1st edition, February 13, 1996, p. 501. Cit. in Taylor, 2001 , p. 44.

6 BOULEZ, Pierre. Concrete (Music). In Notes of an Apprenticeship, pp. 289-290. 
its collage structure Taylor remarks, that efforts to control technology led towards an obsession with technology. ${ }^{7}$

\section{Music beyond technology - a mage and a plumber}

But back to the title of this paper: "Music Beyond Technology?" Apparently, it is not focused on music omitting use of any technology, but rather the mechanical or electronic technology. As already said, music identifies itself with technology in the manner of its structuration, i.e. application of rational procedures employed in the process of its creation. In this sense technology in music cannot be surpassed. But there can be traced various paths leading music beyond above mentioned types of technology:

1. Exceeding technology as a subject of music: Music as a celebration of technology (for example A. Honegger's Pacific 231) versus music conceived as a critique of technology (Steve Reich and his documentary video-opera Three Tales) based on the ironical use of technology for criticizing technology.

2. Overcoming entelechy of technology used in music: Returning technology from objective to subjective position. Technology is no longer understood as an aim of music, but a mere instrument. As an expression of technology per se could be perceived F. Bayle and his idea of Acousmonium constructed in 1970's in Paris.

3. Leaving electronic technology by substituting it by "human" music.

a) Around the middle of 1950's leading composers of the European avant-garde oscillated between electro-acoustic music and purely acoustic music, both resulting mainly into new sonority and timbrality or spacial distribution of sound. (I. Xenakis: Metastaseis, K. Stockhausen: Gruppen etc.) One of the main motives was unsatisfying acoustic result. A transparent example of a sceptical attitude to electronic technology used in compositional process was the case of György Ligeti. ${ }^{8}$ Leaving Hungary after military intervention in 1956 Ligeti settled in Vienna and later he has been invited to Westdeutscher Rundfunk by Herbert Eimert. ${ }^{9}$ During this time as freelancer in the West German Radio studio for electronic music in Cologne (1957-58), he undertook an intense study of the music of Karlheinz Stockhausen, Mauricio Kagel and Pierre Boulez. ${ }^{10}$ During his stay in WDR Ligeti made three compositions: Glissandi (1957), Artikulation with a graphical score made by Rainer Wehinger in 1970's and Pièce électronique Nr. 3 (1957), which remained unfinished from technical reasons. The WDR studio equipment was sim-

7 TAYLOR, op. cit., p. 55.

8 IVERSON, Jennifer. The Emergence of Timbre: Ligeti’s Synthesis of Electronic and Acoustic Music in Atmosphères. Twentieth-century music, 2010, 7, pp. 61-89.

9 HENDERSON, Lol - LEE, Stacey. Ligeti, G. [heslo]. Encyclopedia of Music in the 20th Century. Routledge, 1999, s. 372.

10 György Ligeti [online].[Cit. 9. 10. 2016]. URL: <http://www.schott-music.com/shop/persons/featured/ gyoergy-ligeti/>. 
ply unable to handle forty-eight individual voices that Ligeti envisaged. It was later carried out by means of digital technology by Kees Tazelaar and Johan von Kreij of the Institute of Sonology in 1996.

Following his EM experiments Ligeti recoursed to purely acoustic orchestral setting of compositions Apparitions (1958-59) and Atmosphères (1961) or later in vocal setting of Requiem (1965).

\begin{abstract}
"Although he valued the experience, Ligeti never returned to electronic composition after leaving the WDR studio in 1958. He explained, 'I have found myself over recent years in a state in which I am a little dissatisfied with the acoustic results that one can produce in the electronic studio, independent of which studio equipment is available; the perfection of the studio equipment is beside the point." 11
\end{abstract}

b) Avoiding electronic technology on the grounds of communication barrier between technicians and artists. As P. Boulez put it in his Technology and the Composer: ${ }^{12}$

"Collaboration between scientists and musicians [...] is therefore a necessity that, seen from outside, does not appear to be inevitable. An immediate reaction might be that musical invention can have no need of a corresponding technology; many representatives of the scientific world see nothing wrong with this and justify their apprehensions by the fact that artist creation is specifically the domain of intuition, of the irrational. They doubt whether this utopian marriage of fire and water would be likely to produce anything valid. If mystery is involved, it should remain a mystery: any investigation, any search for a meeting point is easily taken to be sacrilege. Uncertain just what it is that musicians are demanding from them, and what possible terrain there might be for joint efforts, many scientists opt out in advance, seeing only the absurdity of the situation: that is, a mage reduced to begging for help from a plumber! If, in addition, the mage imagines that the plumber's services are all that he needs, then confusion is total. It is easy to see how hard it will be ever to establish a common language for both technological and musical invention." 13

c) Deliberate abandoning of electronics on account of technological ecology. This reason led the Czech artist and performer Petr Nikl to design the Czech Republic pavilion at EXPO 2005 in Aichi as a purely acoustical and game-based exhibition. His Garden of Phantasy and Music followed the same principle as his further exhibitions such as Orbis pictus, Nests of games etc.

11 „Ich befinde mich in den letzten Jahren in einem Zustand, in dem ich ein wenig unbefriedigt bin über die akustischen Ergebnisse dessen, was man im elektronischen Studio machen kann, unabhängig davon, welche Studioeinrichtung vorhanden ist, es geht nicht um die Perfektion der Studioeinrichtung“. Iverson, op. cit., 2010, p. 62.

12 In The Times Literary Supplement, 6 May 1977. Original French text In Passage du XXe siecle, 1e partie, January/July 1977 (Paris, IRCAM) under the title Invention/Recherche. Reprinted in Orientations, Collected Writings, Harvard University Press, Cambridge, MA, 1986, pp. 486-495.

13 Ibid., pp. 5-6. 
"It is an attempt to set up an alternative to the cyber sphere, a kind of technological ecology. We are returning to nature by installing instruments that work on fundamental optical and acoustic principles,' characterized the exhibition Petr Nikl, author of the concept."14

Nowadays, electronic technology is not any more perceived as a necessary instrument for music processing and structuring, rather as a source of creative metaphors brought into music historically by human interactions with it.

\section{Bibliography}

BORN, Georgina. Rationalizing Culture: IRCAM, Boulez, .... Berkeley and Los Angeles: University of California Press, 1995.

BOULEZ, Pierre. Concrete (Music). In Notes of an Apprenticeship, pp. 289-290.

BOULEZ, Pierre. Technology and the Composer. In The Times Literary Supplement, 6 May 1977. Original French text In Passage du XXe siecle, 1e partie, January/July 1977 (Paris, IRCAM) under the title Invention/Recherche. Reprinted in Orientations, Collected Writings, Harvard University Press, Cambridge, MA, 1986, pp. 486-495.

COLLINS, Steve - YOUNG, Sherman. Beyond 2.0: The Future of Music. Equinox Publishing, 2014.

GUERRA, Carlos Gustavo. The Mechanization of intelligence and the human aspects of music. In Eduardo Reck Miranda (ed.). Readings in Music and Artificial Intelligence. Harwood academic publishers, 2000.

HENDERSON, Lol - LEE, Stacey. Ligeti, G. [heslo]. Encyclopedia of Music in the 20th Century. Routledge, 1999.

HOBSBAWM, Eric. The Age of extremes. Vintage, 1st edition, February 13, 1996, p. 501. Cit. in Taylor, 2001.

IVERSON, Jennifer. The Emergence of Timbre: Ligeti's Synthesis of Electronic and Acoustic Music in Atmosphères. Twentieth-century music, 2010, 7.

György Ligeti [online].[Cit. 9. 10. 2016]. URL: <http://www.schott-music.com/shop/persons/ featured/gyoergy-ligeti/>.

TAYLOR, Timothy D. Strange Sounds: Music, Technology and Culture. NY, London: Routledge, 2001.

MF DNES, aho. Češi na Expo: ̌̌íše plná hudby a fantazie. 25. 3. 2005, 9:28 [online].[Cit. 9. 10. 2016]. URL: <http://kultura.zpravy.idnes.cz/cesi-na-expo-rise-plna-hudby-a-fantazie-dhc-/ vytvarne-umeni.aspx?c=2005M071a10B>.

14 MF DNES, aho. Češi na Expo: ř̃̌se plná hudby a fantazie. 25. 3. 2005, 9:28 [online].[Cit. 9. 10. 2016]. URL: 〈http:// kultura.zpravy.idnes.cz/cesi-na-expo-rise-plna-hudby-a-fantazie-dhc-/vytvarne-umeni.aspx?c=2005M071a10B>. 